\title{
Mutant Firefly Luciferase Enzymes Resistant to the Inhibition by Sodium Chloride
}

\author{
Satoshi Yawata ( s-yawata@toadkk.co.jp ) \\ DKK-TOA Corporation https://orcid.org/0000-0002-2572-4107 \\ Kenichi Noda \\ DKK-TOA COPRATION
}

\section{Ai Shimomura}

Research and Development Planning Department, DKK-TOA Corporation, Sayama Saitama 350-1388, Japan

Akio Kuroda

Unit of Molecular Biotechnology, Graduate School of Integrated Sciences for Life, Hiroshima University

\section{Research Article}

Keywords: luciferase, salt inhibition, mutation, alleviation

Posted Date: February 26th, 2021

DOI: https://doi.org/10.21203/rs.3.rs-243105/v1

License: (1) (1) This work is licensed under a Creative Commons Attribution 4.0 International License. Read Full License 


\section{Abstract}

\section{Objectives}

Firefly luciferase, one of the most extensively studied enzymes, has numerous applications. However, luciferase activity is inhibited by sodium chloride. This study aims to expand the applications of firefly luciferase in the presence of sodium chloride.

\section{Results}

We first obtained two mutant luciferase enzymes whose inhibition were alleviated and identified these mutations as Val288lle and Glu488Val. Under dialysis condition ( $140 \mathrm{mM}$ sodium chloride), the wild type was inhibited to $44 \%$ of its original activity level. In contrast, the single mutants, Val288lle and Glu488Val, retained $67 \%$ and $79 \%$ of their original activity, respectively. Next, we introduced Val288lle and Glu488Val mutations into the wild-type luciferase to create a double mutant using site-directed mutagenesis. Notably, the double mutant retained its activity more than $95 \%$ of that in the absence of sodium chloride.

\section{Conclusions}

The mutant luciferase, named luciferase $\mathrm{CR}$, was found to retain its activity in various concentrations of sodium chloride. The inhibition of luciferase $\mathrm{CR}$ under dialysis condition was more alleviated than either Val288lle or Glu488Val alone, suggesting that the effect of the double mutation was cumulative. We discussed the effect of mutations on the alleviation of the inhibition by sodium chloride.

\section{Introduction}

Firefly luciferase, which generates bioluminescence during the oxidative decarboxylation of D-luciferin in the presence of ATP, has been used for numerous applications such as measuring biomass and cellular conditions (Lundin 2000) and protein-protein interaction (Christopoulos and Chiu 1995; OhmuroMatsuyama and Ueda 2016), assaying ATP-related enzymes (Clarke 2005; Lundin 2000), examining Dluciferin-generating enzymes using peptide-modified luciferin or luciferin derivatives (Cali et al. 2006; Liu et al. 2005; Noda et al. 2010; O'Brien et al. 2008), and performing real-time ATP imaging (Grygorczyk et al. 2019). The firefly luciferase gene, luc, has been used as a reporter gene (Wood and Gruber 1996) as well as for bioimaging (Kaskova et al. 2016; Yan et al. 2019). In the food industry, the bioluminescence-based ATP assay has received considerable attention, mainly because as a rapid monitoring system, it can ensure the safety of food products and contact surfaces at critical control points during food processing (Champiat et al. 2001; Darchuk et al. 2015; Davidson et al. 1999; Siragusa et al. 1995).

Although the bioluminescence-based methods have numerous applications, their sensitivity is reduced by the presence of various salts. For example, sodium chloride, a commonly used reagent, is known to inhibit luciferase activity (Aledort et al. 1966). The considerable loss in the sensitivity of the bioluminescence-based method limits the applications in the presence of salts. 
Mutations in the luc gene have been known to produce mutant luciferase enzymes with properties significantly different from those of the wild-type gene. For example, some mutant luciferase enzymes have different bioluminescence spectra (Branchini et al. 2001; Branchini et al. 2005; Branchini et al. 2003; Kajiyama and Nakano 1991; Ugarova et al. 2005), increased enzyme stability (Baggett et al. 2004; Hattori et al. 2002; Kajiyama and Nakano 1993; Koksharov and Ugarova 2012; Law et al. 2006; Pozzo et al. 2018), or different catalytic activity (Aswendt et al. 2019; Fujii et al. 2007; Hirokawa et al. 2002). Previously, we developed the mutant luciferase FM (lle423Leu, Asp436Gly, Leu530Arg) (Fujii et al. 2007), later named LGR by another group (Pozzo et al. 2018), whose higher catalytic activity resulted in a luminescence intensity 10 -fold higher than that of the wild type.

However, mutant luciferase that alleviates inhibition by salt has not been reported. From a random mutant library, this study identified two novel Photinus pyralis mutant luciferase enzymes that were found to retain their activities under dialysis condition. Site-directed mutagenesis of the luc gene was conducted in these mutations to investigate the effect of substitution with other amino acids. Eventually, by combining the optimized mutations in the luc gene, we generated a mutant luciferase enzyme that retains its activity in the presence of various concentrations of sodium chloride.

\section{Methods}

\section{Measurement of luciferase activity}

Luminescence intensity, expressed as the generated light count per second, was measured in 96-well plates (Thermo Fisher, Massachusetts, USA) using a Microplate reader SH-9000 (Corona Electric, Ibaraki, Japan). The reaction was initiated by the addition of $50 \mu \mathrm{l}$ of $1 \mu \mathrm{M}$ ATP and $0.1 \mu \mathrm{M}$ D-luciferin in Tris$\mathrm{HCl}$ buffer $\left(50 \mathrm{mM}\right.$ Tris- $\mathrm{HCl}, \mathrm{pH} 7.4$, and $10 \mathrm{mM} \mathrm{MgCl}_{2}$ ) to $50 \mu \mathrm{l}$ of $0.1 \mathrm{mg} / \mathrm{ml}$ luciferase. Luminescence was measured for $5 \mathrm{~s}$ after injection at $25^{\circ} \mathrm{C}$. Luciferase protein concentrations were determined by measuring the absorbance at $280 \mathrm{~nm}$.

The measurement of the inhibition of luciferase activity in the presence of sodium chloride and other salts

Luciferase reactions were performed in the absence or presence of various concentrations of sodium chloride, potassium chloride, calcium chloride, ammonium chloride, and sodium acetate. To test whether the inhibition is reversible or irreversible, luciferase was dissolved in the Tris- $\mathrm{HCl}$ buffer in $140 \mathrm{mM}$ sodium chloride. After $120 \mathrm{~min}$, luciferase was diluted 10-fold with the Tris-HCl buffer, mixed with $50 \mu \mathrm{l}$ of $10 \mu \mathrm{M}$ ATP and $1 \mu \mathrm{M}$ D-luciferin in the Tris- $\mathrm{HCl}$ buffer to initiate the reaction, and measured. Each experiment was performed with three replicates.

\section{Random mutagenesis and screening}

The PCR Random Mutagenesis Kit (Takara, Shiga, Japan) was used to generate a random mutant library of the Photinus pyralis luc genes. Random mutations were introduced at the rate of one mutation per 
gene. PCR was conducted using the primers 5'-GACTCCATGGAAGACGCCAAAAAC-3' and 5'GACACTCGAGCAATTTGGACTTTCCGCC-3' to generate mutant insert containing restriction sites Ncol and $X$ Xhol. All mutant genes were cloned into the pET-28a vector (Merck, Darmstadt, Germany) to generate recombinant luciferases containing a C-terminal His-tag.

The vectors containing the mutant luc genes were introduced into Escherichia coli HMS174 (DE3) (Merck), spread onto Luria-Bertani agar plates containing kanamycin, and incubated at $37{ }^{\circ} \mathrm{C}$. The colonies were inoculated into a 2YT liquid medium containing kanamycin and induced with $0.1 \mathrm{mM}$ isopropyl-B-D-thiogalactoside (IPTG) in deep-well plates (Watson, Tokyo, Japan) to produce the luciferase protein.

Crude extracts containing mutant luciferase proteins were prepared by freezing and thawing the recombinant bacteria. Each extract was divided into two portions to measure the luminescence intensities in the absence or presence of $140 \mathrm{mM}$ sodium chloride in a reaction mixture containing $50 \mu \mathrm{l}$ each of $1 \mu \mathrm{M}$ ATP and $0.1 \mu \mathrm{M}$ D-luciferin in the Tris-HCl buffer.

\section{Site-directed mutagenesis}

The mutagenesis of the wild-type luc was conducted with primers, designed using the manufacturer's specification, and the KOD-plus mutagenesis kit (Toyobo, Osaka, Japan) to generate 19 substitutions of Val288 and Glu488.

\section{Expression and purification of luciferase}

The recombinant luc was expressed in E. coli HMS174 (DE3). The cells were grown at $37^{\circ} \mathrm{C}$ in $2 \mathrm{YT}$ medium containing $1 \mu \mathrm{g} / \mathrm{ml}$ kanamycin. IPTG was added to the medium for incubation at $25^{\circ} \mathrm{C}$ for $65 \mathrm{~h}$. The induced cells were harvested by centrifugation and stored at $-20^{\circ} \mathrm{C}$. The cell pellets were resuspended in a bacterial cell lysis reagent (B-PER, Thermo Fisher, Massachusetts, USA). After incubation at $25^{\circ} \mathrm{C}$ for $15 \mathrm{~min}$, the whole-cell extracts were isolated by centrifugation at $16,000 \mathrm{~g}$ for 10 min at $4{ }^{\circ} \mathrm{C}$. The His-tagged recombinant luciferase was purified using the Ni Sepharose 6 Fast Flow column (GE Healthcare, Illinois, USA) according to the manufacturer's instructions. Whole-cell extracts were applied to the columns and washed with a binding buffer of $20 \mathrm{mM} \mathrm{NaH}_{2} \mathrm{PO}_{4}, \mathrm{pH} 7.4,500 \mathrm{mM}$ sodium chloride, and $20 \mathrm{mM}$ imidazole. The recombinant luciferase was eluted with an elution buffer (20 $\mathrm{mM} \mathrm{NaH}_{2} \mathrm{PO}_{4}, \mathrm{pH} 7.4,500 \mathrm{mM}$ sodium chloride, and $500 \mathrm{mM}$ imidazole). The elution buffer was exchanged for the Tris-HCl buffer using a PD-10 Desalting Column (GE Healthcare).

\section{Bioluminescence emission spectra}

The bioluminescence emission spectra of the luciferase were measured using a Microplate reader SH9000. The data were collected between 450 and $700 \mathrm{~nm}$. The reactions were initiated by adding $1.8 \mathrm{ml}$ of substrate including $100 \mu \mathrm{M}$ ATP and $10 \mu \mathrm{M}$ D-luciferin into $200 \mu \mathrm{l} \mathrm{of} 0.1 \mathrm{mg} / \mathrm{ml}$ luciferase in the Tris- $\mathrm{HCl}$ buffer. 


\section{Results}

\section{Inhibition of luciferase activity by sodium chloride}

Luciferase is known to be inhibited by sodium chloride (Aledort et al. 1966). Indeed, in the presence of $200 \mathrm{mM}$ sodium chloride, P. pyralis luciferase activity was decreased to $28 \%$ of the control (Fig. 1). Under dialysis condition ( $140 \mathrm{mM}$ sodium chloride), luciferase activity was reduced to $44 \%$ of the control. Since luciferase was inhibited by potassium chloride, calcium chloride, and ammonium chloride, but not sodium acetate (Fig. 1), the inhibition was likely due to the chloride ion.

Next, we tested whether the inhibition of luciferase activity by sodium chloride was reversible. The luciferase was incubated in the $140 \mathrm{mM}$ sodium chloride for 120 min and then diluted 10-fold; its final luciferase activity was compared with that of the luciferase directly diluted in $14 \mathrm{mM}$ sodium chloride. Since there was no significant difference (within $1 \%$ difference in triplicated experiments) between the condition with or without sodium chloride, the inhibition of luciferase activity by sodium chloride was found to be reversible.

\section{Isolation of mutant luciferase enzymes retaining their activities under dialysis condition}

Mutations were randomly introduced into the $P$. pyralis luc gene and then mutant luciferase enzymes that retained more than $60 \%$ of their activities under dialysis condition were selected. Hence, two mutant luciferase enzymes were obtained from approximately twenty thousand transformants. DNA sequencing revealed that the mutations were localized at Val288, changing to Ile (Val288Ile) and at Glu488, changing to Val (Glu488Val), respectively. Luciferase activities of Val288lle and Glu488Val mutants under dialysis condition were $67 \%$ and $79 \%$ of those in the absence of sodium chloride, respectively.

Site-directed mutagenesis was conducted to investigate the effect of substitution with other amino acids at positions 288 and 488 of luciferase (Tables 1 and 2). The substitution of Val288 with nonpolar amino acids, especially Ile, Leu, Met, and Phe, alleviated the inhibition under dialysis condition (Table 1). In contrast, the replacement with polar, positively charged, or negatively charged amino acids, except cysteine, failed to lessen the inhibition under dialysis condition (Table 1). 
Table 1

The effect of Vla288 substitutions on luciferase activity in the presence of $140 \mathrm{mM}$ sodium chloride

\begin{tabular}{|c|c|c|c|c|}
\hline Luciferase & $\begin{array}{l}\text { Substituted } \\
\text { amino acid }\end{array}$ & $\begin{array}{l}\text { Molecular } \\
\text { weight } \\
(\mathrm{g} / \mathrm{mol})\end{array}$ & $\begin{array}{l}\text { Polarity } \\
\text { and charge }\end{array}$ & $\begin{array}{l}\text { Relative luminescence intensity } \\
(\%)^{a}\end{array}$ \\
\hline Wild type & Val & 117.15 & Nonpolar & $44.0 \pm 0.6$ \\
\hline \multirow[t]{19}{*}{ Mutant } & Gly & 75.07 & Nonpolar & $16.3 \pm 0.1$ \\
\hline & Ala & 89.09 & Nonpolar & $21.9 \pm 1.3$ \\
\hline & Pro & 115.13 & Nonpolar & $19.6 \pm 0.4$ \\
\hline & Ile & 131.17 & Nonpolar & $67.2 \pm 2.9$ \\
\hline & Leu & 131.17 & Nonpolar & $46.8 \pm 0.6$ \\
\hline & Met & 149.21 & Nonpolar & $47.3 \pm 0.7$ \\
\hline & Phe & 165.19 & Nonpolar & $46.2 \pm 0.8$ \\
\hline & Trp & 204.23 & Nonpolar & $28.9 \pm 0.9$ \\
\hline & Ser & 105.09 & Polar & $16.3 \pm 0.1$ \\
\hline & Thr & 119.12 & Polar & $25.6 \pm 0.5$ \\
\hline & Cys & 121.16 & Polar & $46.5 \pm 1.3$ \\
\hline & Asn & 132.12 & Polar & $29.3 \pm 0.5$ \\
\hline & Gln & 146.15 & Polar & $32.8 \pm 0.3$ \\
\hline & Tyr & 181.19 & Polar & $38.3 \pm 0.9$ \\
\hline & Lys & 146.19 & Positive & $23.8 \pm 1.8$ \\
\hline & His & 155.15 & Positive & $31.1 \pm 1.4$ \\
\hline & Arg & 174.20 & Positive & $40.8 \pm 0.8$ \\
\hline & Asp & 133.10 & Negative & $16.1 \pm 0.4$ \\
\hline & Glu & 147.13 & Negative & $25.1 \pm 1.0$ \\
\hline $\begin{array}{l}\text { a The relativ } \\
140 \mathrm{mM} \text { so } \\
\text { means } \pm \text { SD }\end{array}$ & $\begin{array}{l}\text { minescence i } \\
\text { chloride by } \\
\text { 3). }\end{array}$ & $\begin{array}{l}\text { sity (\%) wa } \\
\text { in the abse }\end{array}$ & $\begin{array}{l}\text { lculated by } \mathrm{d} \\
\text { of sodium ch }\end{array}$ & $\begin{array}{l}\text { ling the intensity in the presence o } \\
\text { ide. The values are represented as }\end{array}$ \\
\hline
\end{tabular}


Table 2

The effect of Glu488 substitutions on luciferase activity in the presence of $140 \mathrm{mM}$ sodium chloride

\begin{tabular}{|c|c|c|c|c|}
\hline Luciferase & $\begin{array}{l}\text { Substituted } \\
\text { amino acid }\end{array}$ & $\begin{array}{l}\text { Molecular } \\
\text { weight } \\
(\mathrm{g} / \mathrm{mol})\end{array}$ & $\begin{array}{l}\text { Polarity } \\
\text { and charge }\end{array}$ & $\begin{array}{l}\text { Relative luminescence intensity } \\
(\%)^{a}\end{array}$ \\
\hline wild type & Glu & 147.13 & Negative & $44.0 \pm 0.6$ \\
\hline \multirow[t]{19}{*}{ Mutant } & Gly & 75.07 & Nonpolar & $50.2 \pm 0.2$ \\
\hline & Ala & 89.09 & Nonpolar & $43.4 \pm 1.1$ \\
\hline & Pro & 115.13 & Nonpolar & $54.5 \pm 1.2$ \\
\hline & Val & 117.15 & Nonpolar & $78.7 \pm 1.3$ \\
\hline & Ile & 131.17 & Nonpolar & $58.0 \pm 0.5$ \\
\hline & Leu & 131.17 & Nonpolar & $62.0 \pm 0.5$ \\
\hline & Met & 149.21 & Nonpolar & $73.1 \pm 0.7$ \\
\hline & Phe & 165.19 & Nonpolar & $56.6 \pm 1.1$ \\
\hline & Trp & 204.23 & Nonpolar & $40.0 \pm 1.2$ \\
\hline & Ser & 105.09 & Polar & $50.9 \pm 1.0$ \\
\hline & Thr & 119.12 & Polar & $66.8 \pm 1.7$ \\
\hline & Cys & 121.16 & Polar & $69.5 \pm 1.1$ \\
\hline & Asn & 132.12 & Polar & $30.9 \pm 1.1$ \\
\hline & Gln & 146.15 & Polar & $34.8 \pm 1.4$ \\
\hline & Tyr & 181.19 & Polar & $40.2 \pm 0.7$ \\
\hline & Lys & 146.19 & Positive & $22.9 \pm 1.3$ \\
\hline & His & 155.15 & Positive & $32.8 \pm 0.5$ \\
\hline & Arg & 174.20 & Positive & $43.1 \pm 1.0$ \\
\hline & Asp & 133.10 & Negative & $68.1 \pm 1.2$ \\
\hline $\begin{array}{l}\text { a Relative lu } \\
140 \mathrm{mM} \text { so } \\
\text { means } \pm \text { SD }\end{array}$ & $\begin{array}{l}\text { escence inter } \\
\text { c chloride by } \\
\text { 3). }\end{array}$ & $\begin{array}{l}\text { (\%) was ca } \\
\text { in the abse }\end{array}$ & $\begin{array}{l}\text { ated by divid } \\
\text { of sodium } \mathrm{cl}\end{array}$ & $\begin{array}{l}\text { the intensity in the presence of } \\
\text { de. The values are represented as }\end{array}$ \\
\hline
\end{tabular}

Alternatively, the substitution of Glu488 with nonpolar amino acids, except Ala and Trp, mostly improved the inhibition (Table 2). Also, the replacement of Glu488 with Ser, Thr, Cys, and Asp also alleviated the 
inhibition. By contrast, the substitution with positively charged amino acids failed to ease the inhibition (Table 2). Finally, the best substitution at Val288 and Glu488 was found to be lle and Val, respectively.

\section{The characterization of a Val288lle and Glu488Val double mutant luciferase enzyme}

A luc gene encoding the Val288Ile and Glu488Val double mutant luciferase, tentatively named CR for chloride ion resistance, was constructed with site-directed mutagenesis. Bioluminescence activities of the wild-type, single mutants Val288lle and Glu488Val, the double mutant CR, and the FM mutant that we previously developed, were tested under dialysis condition and in the absence of sodium chloride (Fig. 2).

The luminescence intensity of the CR double mutant luciferase under dialysis condition retained more than $95 \%$ of its activity compared to that in the absence of sodium chloride. The inhibition of CR under dialysis condition was more alleviated than either Val288lle or Glu488Val alone, suggesting that the effect of the double mutation was cumulative. Unexpectedly, the luminescence intensity of the double mutant luciferase was found to be $460 \%$ higher than that of the wild type (Fig. 2). Meanwhile, the luminescent intensities of Val288Ile and Glu488Val were 310\% and 280\% higher than that of the wild type, respectively, indicating that these mutations not only alleviated the inhibition by sodium chloride but also increased the luciferase activity. Alternatively, the luminescence intensity of the FM mutant (Fujii et al. 2007) increased $500 \%$ higher than that of the wild type in the absence of sodium chloride but failed to alleviate the inhibition by sodium chloride (Fig. 2), indicating that mutations increasing the luminescence intensity do not always lessen the inhibition by sodium chloride.

Next, we evaluated the inhibition of wild type, the double mutant CR, and the FM mutant by various concentrations of sodium chloride (Fig. 3). Compared to the wild type, the double mutant CR retained its activity in various concentrations of sodium chloride. In contrast, the FM mutant was more susceptible to sodium chloride inhibition than the wild type. We cocluded the double mutant CR as a new type of mutant luciferase resistant to the inibition by sodium chloride.

Next, we evaluated the wavelength of bioluminescence emission by the wild type and CR. The patterns of bioluminescence wavelength were not significantly different between the enzymes (Fig. 4). The maximum wavelength emitted by luciferase CR was $556 \mathrm{~nm}$.

\section{ATP assay using luciferase CR}

We previously developed the higher catalytic mutant luciferase FM (Fujii et al. 2007) and applied this enzyme for efficient assays for ATP as well as D-luciferin-generating enzymes using peptide-modified luciferin (Noda et al. 2010; Noda et al. 2008; Urata et al. 2009). Here we found that luciferase CR showed higher luminescence than FM within various ATP concentrations in the presence of sodium chloride (Fig. 5). Therefore, the mutant luciferase CR would expand the applications of luciferase in the presence of sodium chloride. 


\section{Discussion}

In this report, two mutant luciferase enzymes that retained more than $60 \%$ of their original activity under dialysis condition, were obtained from approximately 20,000 candidates; the mutations were located at Val288 and Glu488. The double mutant luciferase CR (Val288lle and Glu488Val) retained more than 95\% of its original activity under dialysis condition. Our study is the first report of mutant luciferases that lessen the inhibition by salt. Luciferase CR would be useful for the application of firefly luciferase in the presence of sodium chloride.

Electrostatic interaction is a significant force in mediating intramolecular and intermolecular interactions for determining the structure, dynamics, and function of biomolecules (Neves-Petersen and Petersen 2003). In an aqueous solution, ions and small molecules of opposite charges accumulate around a highly charged biomolecule, resulting in electrical neutralization of the biomolecule, or the shielding effect. In the screening or shielding effect, salt molecules shield the long-range electrostatic repulsive forces between the intramolecular charges, decrease the repulsive interactions, and enhance the hydrophobic effects, thus increasing enzyme stability (Curtis et al. 1998; Valente et al. 2005). On the other hand, certain types of salt ions could also shield enzyme-substrate electrostatic interactions, thus inhibiting enzyme activities. The salt inhibition of luciferase might indicate that the positive effect of salt ions could not overcome the negative effect of chloride ions.

The firefly luciferase enzyme, consisting of a large 440 amino acid N-terminal domain and a small 110 amino acid C-terminal domain connected by a short hinge (Fig. 6), catalyzes a sequence of reactions, i.e., adenylation and oxidation, that convert luciferin into an electronically excited state oxyluciferin that emits light (Conti et al. 1996). The interface between the two domains contains the active site, with the Nterminal domain contributing most of the residues responsible for substrate binding, while the C-terminal domain introduces Lys529 and Lys443 that participate in adenylation and oxidation reactions, respectively (Sundlov et al. 2012). The Val288 residue is localized within $5 \AA$ apart from Thr527 that interacts with the active site Lys529 (Fig. 6). Therefore, the mutation of Val288 to lle might have changed the localization of Thr527 and strengthened the enzyme-substrate electrostatic interactions, resulting in the alleviation of the inhibition.

On the contrary, the Glu488 residue is localized in the flexible region away from the active sites in the Nterminal domain (Fig. 6). It was recently reported that the substitution of histidine in the same flexible region by aspartate (His461Asp) decreased ATP binding affinity and shifted its optimum temperature of activity (Rahban et al. 2017). It was also reported that the substitution of His489 by aspartate (His489Asp) increased protein rigidity but only slightly improved its thermal stability (Rahban et al. 2017). Therefore, the finding that Glu488 in the flexible region contributes in alleviating the inhibition by chloride ion is novel.

\section{Declarations}


Acknowledgments

We thank Mr. S. Arakawa of DKK-TOA Corporation and Dr. H. Funabashi of Hiroshima University for their helpful discussion.

\section{Compliance with Ethical Standards}

\section{Funding}

This study was funded by DKK-TOA Corporation.

\section{Conflict of interest}

S.Y., K.N. and A.S. are employees of DKK-TOA Corporation. A.K. has no conflicts of interest.

\section{Ethics approval}

This article does not contain any studies with human participants or animals performed by any of the authors.

\section{Availability of data and material}

The datasets generated during and/or analyzed during the current study are available from the corresponding author upon reasonable request.

\section{Author contributions}

S.Y. and K.N. developed the original concept of this study. S.Y., K.N. and A.S. performed the experiments. A.K. discussed the experimental data and supervised writing of the manuscript. All authors and contributed to manuscript writing and approve of its contents.

\section{References}

Aledort LM, Weed RI, Troup SB (1966) Ionic effects on firefly bioluminescence assay of red blood cell ATP. Anal Biochem 17:268-277. https://doi.org/10.1016/0003-2697(66)90205-3

Aswendt M, Vogel S, Schäfer C, Jathoul A, Pule M, Hoehn M (2019) Quantitative in vivo dual-color bioluminescence imaging in the mouse brain. Neurophotonics 6:025006.

https://doi.org/10.1117/1.NPh.6.2.025006

Baggett B, Roy R, Momen S, Morgan S, Tisi L, Morse D, Gillies RJ (2004) Thermostability of firefly luciferases affects efficiency of detection by in vivo bioluminescence. Mol Imaging 3:324-332. https://doi.org/10.1162/1535350042973553 
Branchini BR, Magyar RA, Murtiashaw MH, Portier NC (2001) The role of active site residue arginine 218 in firefly luciferase bioluminescence. Biochemistry 40:2410-2418. 10.1021/bi002246 m

Branchini BR, Southworth TL, Khattak NF, Michelini E, Roda A (2005) Red- and green-emitting firefly luciferase mutants for bioluminescent reporter applications. Anal Biochem 345:140-148. https://doi.org/10.1016/j.ab.2005.07.015

Branchini BR, Southworth TL, Murtiashaw MH, Boije H, Fleet SE (2003) A mutagenesis study of the putative luciferin binding site residues of firefly luciferase. Biochemistry 42:10429-10436. https://doi.org/10.1021/bi030099x

Cali JJ, Ma D, Sobol M et al. (2006) Luminogenic cytochrome P450 assays. Expert Opin Drug Metab Toxicol 2:629-645. https://doi.org/10.1517/17425255.2.4.629

Champiat D, Matas N, Monfort B, Fraass H (2001) Applications of biochemiluminescence to HACCP. Luminescence 16:193-198. https://doi.org/10.1002/bio.647

Christopoulos TK, Chiu NH (1995) Expression immunoassay. Antigen quantitation using antibodies labeled with enzyme-coding DNA fragments. Anal Chem 67:4290-4294.

https://doi.org/10.1021/ac00119a014

Clarke SC (2005) Pyrosequencing: nucleotide sequencing technology with bacterial genotyping applications. Expert Rev Mol Diagn 5:947-953. https://doi.org/10.1586/14737159.5.6.947

Conti E, Franks NP, Brick P (1996) Crystal structure of firefly luciferase throws light on a superfamily of adenylate-forming enzymes. Structure 4:287-298. https://doi.org/10.1016/s0969-2126(96)00033-0

Curtis RA, Prausnitz JM, Blanch HW (1998) Protein-protein and protein-salt interactions in aqueous protein solutions containing concentrated electrolytes. Biotechnol Bioeng 57:11-21. https://doi.org/10.1002/(sici)1097-0290(19980105)57:1<11::aid-bit2>3.0.co;2-y

Darchuk EM, Waite-Cusic J, Meunier-Goddik L (2015) Effect of commercial hauling practices and tanker cleaning treatments on raw milk microbiological quality. J Dairy Sci 98:7384-7393. https://doi.org/10.3168/jds.2015-9746

Davidson CA, Griffith CJ, Peters AC, Fielding LM (1999) Evaluation of two methods for monitoring surface cleanliness-ATP bioluminescence and traditional hygiene swabbing. Luminescence 14:33-38. https://doi.org/10.1002/(sici)1522-7243(199901/02)14:1<33::Aid-bio514>3.0.Co;2-i

Fujii H, Noda K, Asami Y, Kuroda A, Sakata M, Tokida A (2007) Increase in bioluminescence intensity of firefly luciferase using genetic modification. Anal Biochem 366:131-136. https://doi.org/10.1016/j.ab.2007.04.018 
Grygorczyk R, Boudreault F, Tan JJ, Ponomarchuk O, Sokabe M, Furuya K (2019) Mechanosensitive ATP release in the lungs: New insights from real-time luminescence imaging studies. Curr Top Membr 83:4576. https://doi.org/10.1016/bs.ctm.2019.02.001

Hattori N, Kajiyama N, Maeda M, Murakami S (2002) Mutant luciferase enzymes from fireflies with increased resistance to benzalkonium chloride. Biosci Biotechnol Biochem 66:2587-2593.

https://doi.org/10.1271/bbb.66.2587

Hirokawa K, Kajiyama N, Murakami S (2002) Improved practical usefulness of firefly luciferase by gene chimerization and random mutagenesis. Biochim Biophys Acta 1597:271-279.

https://doi.org/10.1016/s0167-4838(02)00302-3

Kajiyama N, Nakano E (1991) Isolation and characterization of mutants of firefly luciferase which produce different colors of light. Protein Eng 4:691-693. https://doi.org/10.1093/protein/4.6.691

Kajiyama N, Nakano E (1993) Thermostabilization of firefly luciferase by a single amino acid substitution at position 217. Biochemistry 32:13795-13799. https://doi.org/10.1021/bi00213a007

Kaskova ZM, Tsarkova AS, Yampolsky IV (2016) 1001 lights: luciferins, luciferases, their mechanisms of action and applications in chemical analysis, biology and medicine. Chem Soc Rev 45:6048-6077. https://doi.org/10.1039/c6cs00296j

Koksharov MI, Ugarova NN (2012) Approaches to engineer stability of beetle luciferases. Comput Struct Biotechnol J 2:e201209004. https://doi.org/10.5936/csbj.201209004

Law GH, Gandelman OA, Tisi LC, Lowe CR, Murray JA (2006) Mutagenesis of solvent-exposed amino acids in Photinus pyralis luciferase improves thermostability and pH-tolerance. Biochem J 397:305-312. https://doi.org/10.1042/bj20051847

Liu JJ, Wang W, Dicker DT, El-Deiry WS (2005) Bioluminescent imaging of TRAIL-induced apoptosis through detection of caspase activation following cleavage of DEVD-aminoluciferin. Cancer Biol Ther 4:885-892. https://doi.org/10.4161/cbt.4.8.2133

Lundin A (2000) Use of firefly luciferase in ATP-related assays of biomass, enzymes, and metabolites. Methods Enzymol 305:346-370. https://doi.org/10.1016/s0076-6879(00)05499-9

Neves-Petersen MT, Petersen SB (2003) Protein electrostatics: a review of the equations and methods used to model electrostatic equations in biomolecules-applications in biotechnology. Biotechnol Annu Rev 9:315-395. https://doi.org/10.1016/s1387-2656(03)09010-0

Noda K, Goto H, Murakami Y, Ahmed AB, Kuroda A (2010) Endotoxin assay by bioluminescence using mutant firefly luciferase. Anal Biochem 397:152-155. https://doi.org/10.1016/j.ab.2009.10.025 
Noda K, Matsuno T, Fujii H, Kogure T, Urata M, Asami Y, Kuroda A (2008) Single bacterial cell detection using a mutant luciferase. Biotechnol Lett 30:1051-1054. https://doi.org/10.1007/s10529-008-9643-3

O'Brien MA, Moravec RA, Riss TL, Bulleit RF (2008) Homogeneous, bioluminescent proteasome assays. Methods Mol Biol 414:163-181. https://doi.org/10.1007/978-1-59745-339-4_13

Ohmuro-Matsuyama Y, Ueda H (2016) A Protein-Protein Interaction Assay FlimPIA Based on the Functional Complementation of Mutant Firefly Luciferases. Methods Mol Biol 1461:131-142.

https://doi.org/10.1007/978-1-4939-3813-1_10

Pozzo T, Akter F, Nomura Y, Louie AY, Yokobayashi Y (2018) Firefly Luciferase Mutant with Enhanced Activity and Thermostability. ACS Omega 3:2628-2633. https://doi.org/10.1021/acsomega.7b02068

Rahban M, Salehi N, Saboury AA et al. (2017) Histidine substitution in the most flexible fragments of firefly luciferase modifies its thermal stability. Arch Biochem Biophys 629:8-18.

https://doi.org/10.1016/j.abb.2017.07.003

Siragusa GR, Cutter CN, Dorsa WJ, Koohmaraie M (1995) Use of a Rapid Microbial ATP Bioluminescence Assay to Detect Contamination on Beef and Pork Carcasses ( $\dagger$ ). J Food Prot 58:770-775.

https://doi.org/10.4315/0362-028x-58.7.770

Sundlov JA, Fontaine DM, Southworth TL, Branchini BR, Gulick AM (2012) Crystal structure of firefly luciferase in a second catalytic conformation supports a domain alternation mechanism. Biochemistry 51:6493-6495. https://doi.org/10.1021/bi300934s

Ugarova NN, Maloshenok LG, Uporov IV, Koksharov MI (2005) Bioluminescence spectra of native and mutant firefly luciferases as a function of pH. Biochemistry (Mosc) 70:1262-1267. https://doi.org/10.1007/s10541-005-0257-2

Urata M, Iwata R, Noda K, Murakami Y, Kuroda A (2009) Detection of living Salmonella cells using bioluminescence. Biotechnol Lett 31:737-741. https://doi.org/10.1007/s10529-009-9924-5

Valente JJ, Verma KS, Manning MC, Wilson WW, Henry CS (2005) Second virial coefficient studies of cosolvent-induced protein self-interaction. Biophys J 89:4211-4218.

https://doi.org/10.1529/biophysj.105.068551

Wood KV, Gruber MG (1996) Transduction in microbial biosensors using multiplexed bioluminescence. Biosens Bioelectron 11:207-214. https://doi.org/10.1016/0956-5663(96)88407-7

Yan Y, Shi P, Song W, Bi S (2019) Chemiluminescence and Bioluminescence Imaging for Biosensing andTherapy: In Vitro and In Vivo Perspectives. Theranostics 9:4047-4065.

https://doi.org/10.7150/thno.33228 
Figures

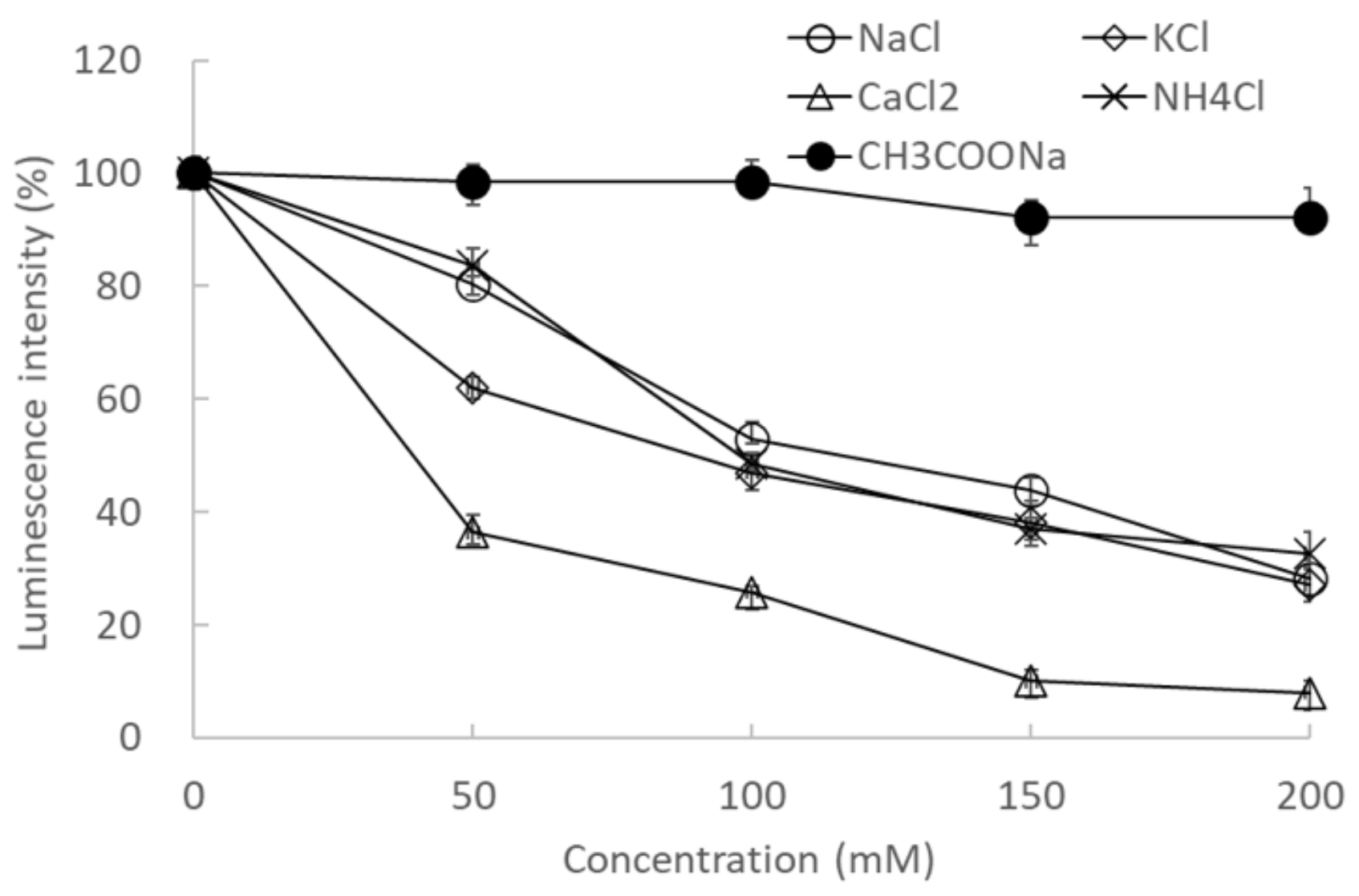

Figure 1

The effects of various concentrations of sodium chloride, potassium chloride, calcium chloride, ammonium chloride, and sodium acetate on the activity of the wild-type luciferase The values are represented as means $\pm S D(n=3)$. 


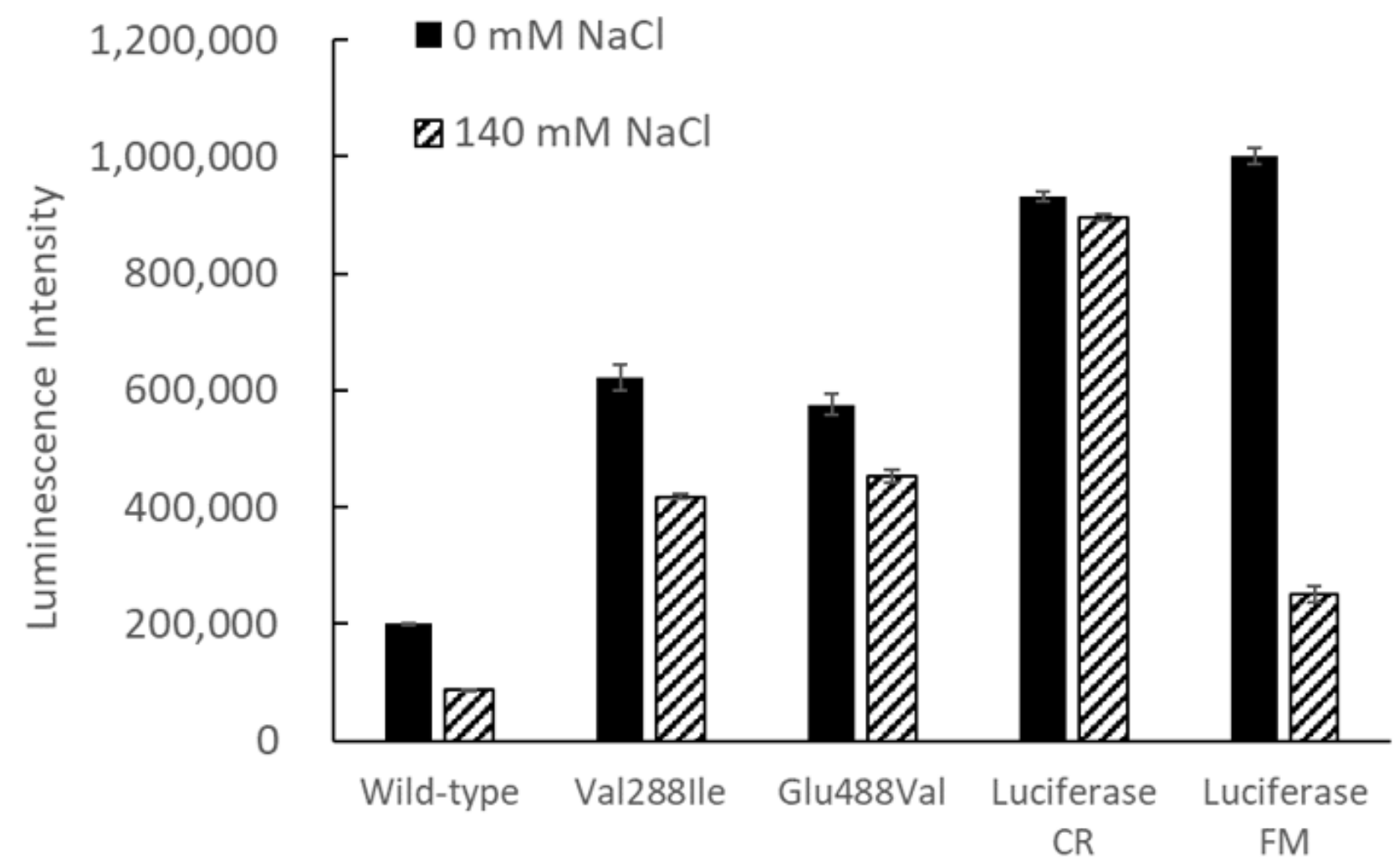

Figure 2

The inhibition of the activity of the wild-type and mutant luciferases by sodium chloride The luminescence intensity of the luciferase reactions in the absence or presence of $140 \mathrm{mM}$ sodium chloride was measured. The values are represented as means $\pm S D(n=3)$. 


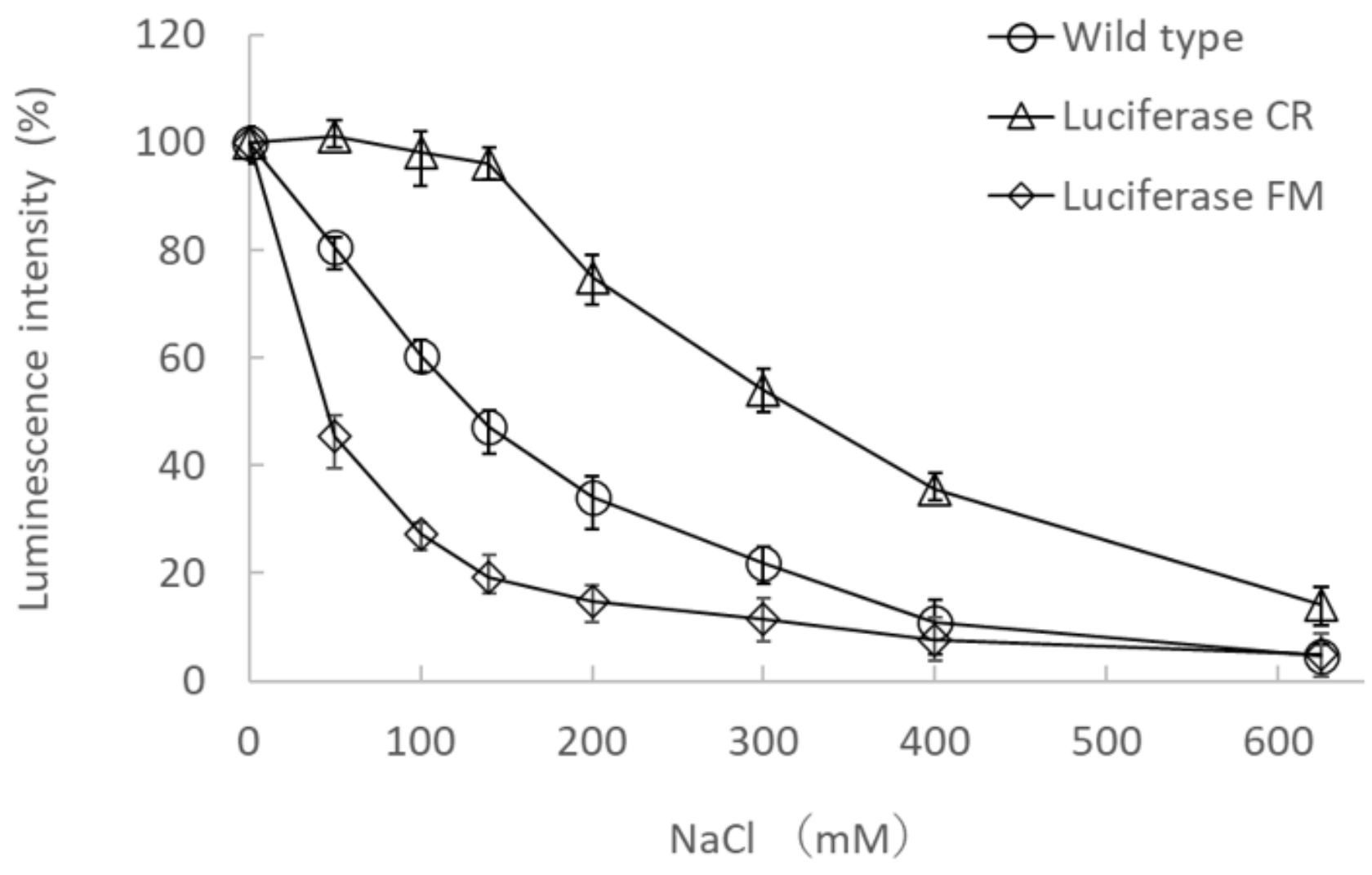

Figure 3

The effect of sodium chloride concentration on the activity of the wild-type, luciferase $\mathrm{CR}$, and FM The luminescence intensity of the luciferase reactions in various concentrations of sodium chloride was measured. The values are represented as means $\pm \operatorname{SD}(n=3)$. 


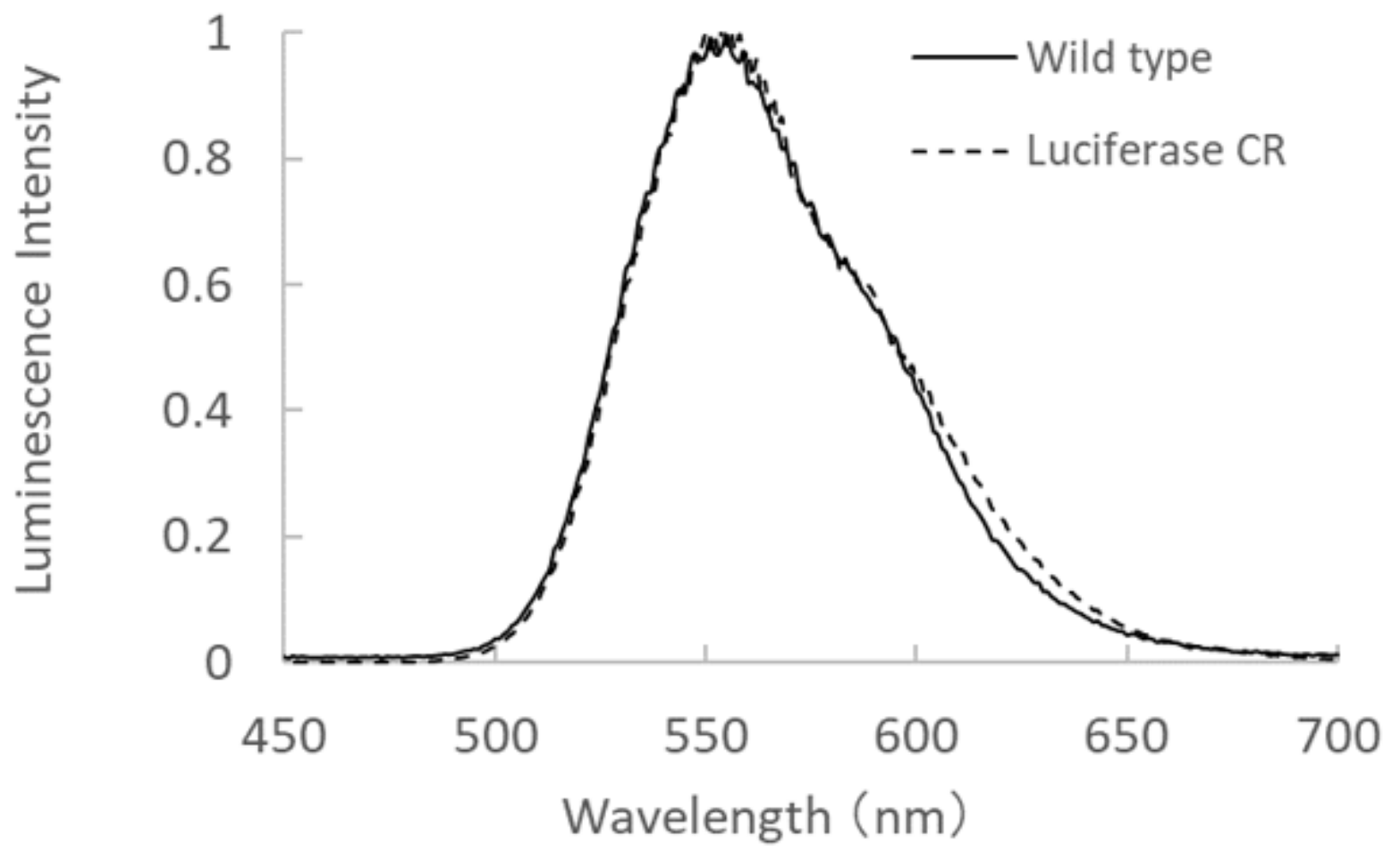

Figure 4

The bioluminescence emission spectra of the wild-type and luciferase CR 


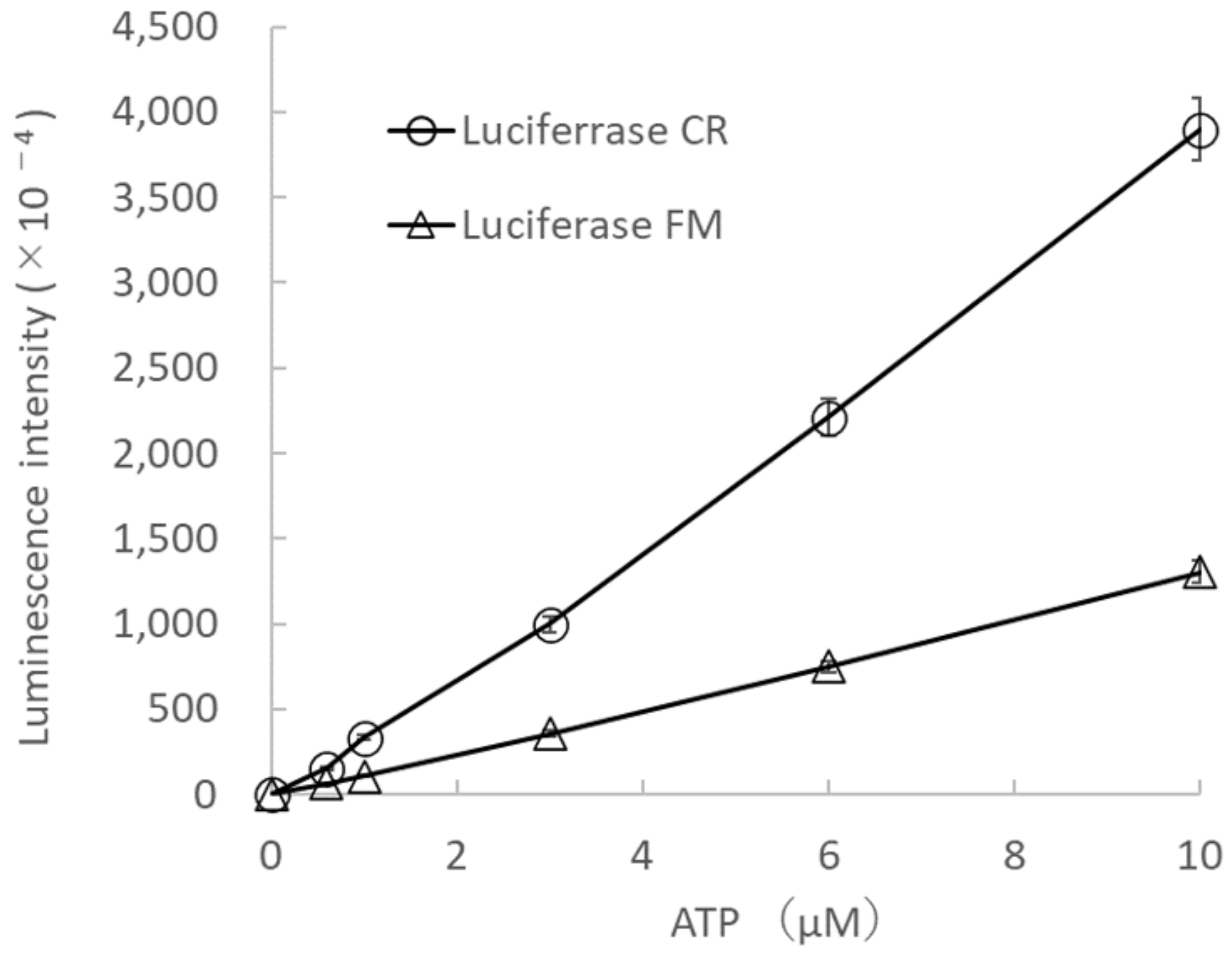

\section{Figure 5}

The luminescence intensity of the luciferase reactions in various concentrations of ATP The luminescence intensity of the luciferase reactions in various concentrations of ATP was measured. The values are represented as means $\pm S D(n=3)$. 


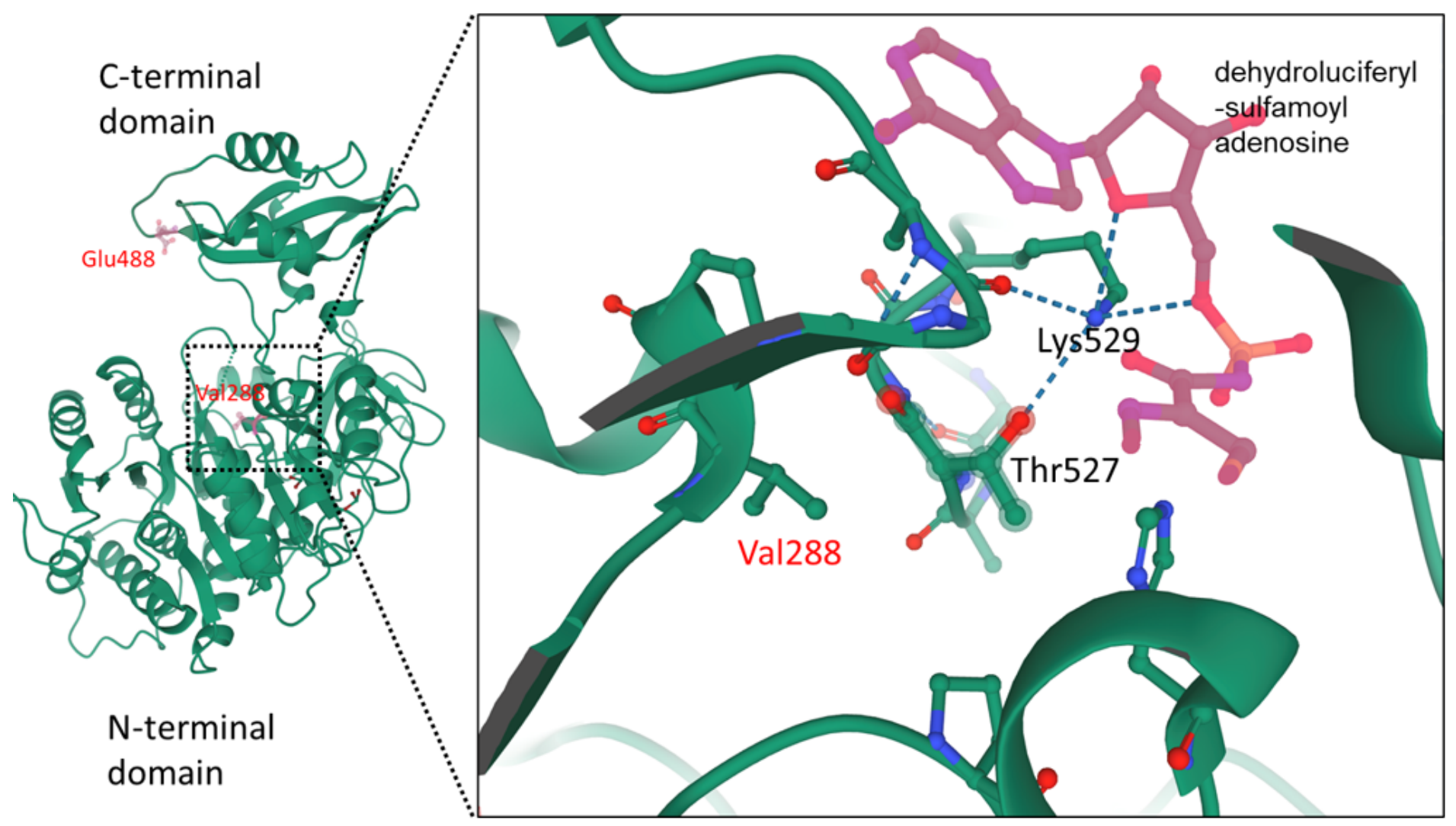

Figure 6

The three-dimensional structure of Photinus pyralis luciferase and the locations of mutations in the luciferase CR The active sites with a substrate analog (dehydroluciferyl-sulfamoyl adenosine) are indicated in the right box. The amino acid substitutions (red) in the luciferase CR were indicated. This figure was created based on the crystal structure (Protein Data Bank ID code 4G36) of Photinus pyralis luciferase. 